\title{
Article
}

\section{Authenticity and Historicity}

\author{
Lucas, Peter
}

Available at http://clok.uclan.ac.uk/11876/

Lucas, Peter ORCID: 0000-0002-5391-3087 (2014) Authenticity and

Historicity. Philosophy, Psychiatry, \& Psychology, 21 (3). pp. 233-235. ISSN 1071-6076

It is advisable to refer to the publisher's version if you intend to cite from the work. http://dx.doi.org/10.1353/ppp.2014.0035

For more information about UCLan's research in this area go to http://www.uclan.ac.uk/researchgroups/ and search for < name of research Group>.

For information about Research generally at UCLan please go to http://www.uclan.ac.uk/research/

All outputs in CLoK are protected by Intellectual Property Rights law, including Copyright law. Copyright, IPR and Moral Rights for the works on this site are retained by the individual authors and/or other copyright owners. Terms and conditions for use of this material are defined in the policies page.

\section{CLoK}

Central Lancashire online Knowledge www.clok.uclan.ac.uk

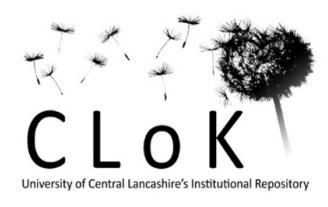




\section{PROJECT MUSE}

\section{Authenticity and Historicity}

\section{Peter Lucas}

Philosophy, Psychiatry, \& Psychology, Volume 21, Number 3, September 2014, pp. 233-235 (Article)

Published by Johns Hopkins University Press

DOI: https://doi.org/10.1353/ppp.2014.0035

$\Rightarrow$ For additional information about this article https://muse.jhu.edu/article/580231 


\section{AuthentiCITY AND HISTORICITY}

E

RLer And Hope conclude that the concept of authenticity is a rich one, with a wide variety of promising applications in psychiatry and psychotherapy. Nevertheless, they acknowledge that there are tensions within the concept-most notably, between the 'true self' account due to Charles Taylor, and accounts due to DeGrazia and others, which put more emphasis on self-creation and autonomy. If, in invoking the concept, a patient might either be trying to capture something about the importance of self-creation, or trying to capture something about the importance of discovering/maintaining her true self, or trying to avoid self-deception, or trying to work out what she really values (Taylor 1991, 36), we might reasonably wonder how much value such an endlessly flexible concept can really have. A more integrated (and thus more useful) concept of authenticity can be found in the tradition of post-Kantian European philosophy with which the concept originates. In particular, it is with reference to the primarily Hegelian notion of the historicity of the self that the real integrity of the concept can be grasped.

The most influential philosophical accounts of authenticity implicitly reject both the idea that the self could be entirely self-created, and the idea that the self could be entirely the object of discovery.

\section{Peter Lucas}

Heidegger and Sartre disagree on many points, but they agree on the idea that the historicity of the self should be conceived in terms of thrown projection. Thrownness (Heidegger, 1927/1962, \$29) refers to the contingency of our physical and cultural circumstances, and their recalcitrance in the face of our projects and strivings. Our particular spatial, temporal, social, and cultural location in this world is something we did not choose. That I am the son of my parents may be a necessary truth. But there was no necessity that I should be born at all, or that I would be born when and where I was born. My life as it has been lived is a result of innumerable contingencies, with respect to which I have never exercised complete control.

At the same time, it is an evident feature of this life that I make decisions in it and about it. I find myself with projects, and it is in light of these projects that I am able to make decisions. (Equally, when I find myself unable to decide, it is in light of my projects that I am paralyzed with indecision.) These projects were never simply chosen. They grew out of, and into, other projects-in a process that began earlier than my earliest memories. When I decide I project into the future, or into possible futures, and the projective character of choice contributes to the distinctive temporal character of my existence (Heidegger, 1927/1962, \$31). Just as in a melody each note is inflected both by those that preceded it and those that are anticipated, so human existence as thrown-projection is inflected at every moment by a specific past and at least one possible future. 
Where existence has the above character, authenticity cannot be either a matter of sheer selfdiscovery or sheer self-creation. For the self to be simply the object of discovery, it would have to be the case that my projects were simply discovered, and of course this is not the case-those projects are laced at every turn with decisions that I make. On the other hand, for the self to be simply the object of self-creation, it would have to be projection without thrownness-in a kind of year zero of the self, at which all clocks were reset, and we were free to choose outside of all 'situations.' On the view of the self as thrown-projection, authenticity involves avoiding the kind of 'bad faith' implicit in such views. For Sartre, there are equal and opposite failures in (1) the failure to acknowledge the facts of our situation (c.f. his example of the woman seduced, who closes her eyes to the seducer's actions, pretending that they are not really happening [Sartre, 1943/1991, part 1, chapter $2, \mathbb{S I I}$ ), and (2) the failure to acknowledge that, as thrown-projection, we nevertheless transcend this situation (the example of the waiter, who effectively reduces himself to his role, implicitly denying that he could be something other than a waiter [Sartre, 1943/1991, part 1, chapter 2, \$ II]). Thus understood, authenticity could be conceived as a mean between the twin vices of regarding oneself as essentially an object to be discovered and regarding oneself as free to be whatever one chooses to be.

It might be responded that the target is impossible to hit: the line between the two alternatives is vanishingly thin, and in fact the way one lives one's life must be marked inevitably by one or other of the above vices (we are doomed to emphasize 'facticity' at the expense of 'transcendence,' or vice versa). To see our way around this problem, it is helpful to consider Heidegger's portrayal of authenticity, in which authenticity is unequivocally an achievement (Heidegger, 1927/1962, \$27). Authenticity is the outcome of a struggle to free oneself from the 'they-self'- the self that is entangled in the viewpoints and judgments of others, in such a way that its decisions are never properly its own. Authenticity of this type is possible because neither the projects we engage in, nor the view of reality that forms the background to them, need be taken over at second hand from others. This highlights a key dimension of our thrown-projection: we do not simply live thrown-projection, we seek to understand ourselves and the world into which we are thrown - and we may do so authentically or inauthentically. Without this self-interpretive element, the historicity of the self is incomplete.

Making allowance for the self-interpretive element in authenticity may seem to push us in the direction of a narrative view of the self (Taylor $1989,47)$ and this in turn may seem to push us back in the direction of a self-creation view. Nevertheless, a historical conception of the self can correct the tendency of narrative views of the self to overemphasize self-creation. History is, of course, a type of narrative. But the object of a historical narrative is not a fiction. The self as the object of a historical narrative would be constrained by the facts in a way that the self as object of mere narrative need not be.

With this the pendulum may seem to swing back too far toward the self-discovery view: history aims to discover the facts, and provide a faithful narrative of them (within the familiar constraints that apply to any narrative). But 'history' has a dual sense. On the one hand it refers to the unfolding sequence of human actions leading up to the present. On the other hand it refers to the narrative of those actions. A historical narrative of the self must be historical in both senses. On the one hand it is straightforwardly an attempt to give an account of a life that is being lived. On the other hand, it is an event in that life. Human beings not only write history, they also make history; and every account of history is in its own small (or sometimes large) way a historical event. (It might equally be said that historical events are contributions to the writing of history. When a public figure makes a significant decision, she will always have at least half an eye on how she will be viewed by posterity. The first historian of the event, we might say, is the historical agent herself-just as in our own lives we can reasonably be said to be the first historians of our own actions, when we reflect on how they will be interpreted by others.) Thus, the resolution of the tension between self-creation and self-discovery is built into the historical view of the self from the start: a contribution to the history 
of the self is always both an attempt to faithfully record that self, and an original act of self-creation.

There is, however, a final dimension of authenticity to be taken into account: that of the contributions of others to one's historical narrative. The first historian of J. Smith was not Smith himself but-in all probability-his parents (we do not announce our own birth!). Somehow we must properly incorporate the contributions of others into our histories. Our narrative does not just aim to be faithful to the facts, it also aims to be faithful to our sources-and being faithful to our sources may well mean deferring to them in areas in which they have greater knowledge.

Once the historicity of human existence is taken into account, the apparent tensions in the concept of authenticity seem to resolve themselves. In the production of the historical narrative of our own existence we must aim to be (1) faithful to the projects that animate that existence, (2) faithful to the facts, (3) faithful to ourselves in being the authors of our own histories, and (4) faithful to the sources on which we draw, whose authority might outstrip ours on many points. This account is compatible with Charles Taylor's view of authenticity, which is premised on the idea that "There is a certain way of being human that is my way" (Taylor 1991, 28-9). But on this view, it is as the author of my own history that I may discharge my role authentically, or not. Against this background, a patient who is concerned whether consenting to treatment is compatible with authenticity need not be interpreted as presenting us with a version of the self-discovery versus self-creation conundrum. Rather, she can be seen as seeking advice on how to make sense of herself-essentially, on how to continue her own (hi)story.

\section{REFERENCES}

Erler, A., and Hope, T. 2014. Mental disorder and the concept of authenticity. Philosophy, Psychiatry, \& Psychology 21, no. 3:219-32.

Heidegger, M. 1927/1962. Being and time, trans. J. Macquarrie and E. Robinson. Oxford: Blackwell.

Sartre, J-P. 1943/1991. Being and nothingness, trans. H. E. Barnes. London: Routledge.

Taylor, C. 1989. Sources of the self. Cambridge, MA: Cambridge University Press.

. 1991. The ethics of authenticity. Cambridge, MA: Harvard University Press. 